\title{
Faulting, shallow seismicity and seismic hazard analysis for the Costa Rican Central Valley
}

\author{
M. Fernández ${ }^{a}, *, W$. Rojas $^{b}$ \\ ${ }^{a}$ Centro de Investigaciones Geofísicas (CIGEFI), Universidad de Costa Rica and Red Sismológica Nacional (RSN: ICE-UCR) Apdo 35-2060, San Jose, \\ Costa Rica, Central America \\ ${ }^{\mathrm{b}}$ Escuela Centroamericana de Geologia, Universidad de Costa Rica and Red Sismologica Nacional (RSN: ICE-UCR) Apdo 35-2060, San Jose, \\ Costa Rica, Central America
}

\begin{abstract}
Faulting, shallow seismicity $(0-30 \mathrm{~km})$, and seismic hazard of the Costa Rican Central Valley were analyzed. Faults in the study area are oriented northwest or northeast. There is an active fault system in the south flank of the Central Volcanic Ridge and another in the north flank of the Talamanca Ridge. Faults of these systems have generated 15 destructive earthquakes in the area during the last 228 years all of them shallow and their locations show one cluster near the Poas Volcano and another southward the Central Valley. These earthquakes have damaged cities of the Central Valley, two of them destroyed Cartago city and almost 1000 people were killed. Regarding recent seismicity, there are three main seismic sources at the Central Volcanic Ridge: Irazu, Bajo de la Hondura and Poas and other three in the Talamanca Ridge: Puriscal, Los Santos and Pejibaye.

A seismic hazard map for the Metropolitan Area of San José has been elaborated, based on local tectonic and seismic information. The area for the hazard computation covers an area of $20 \times 15 \mathrm{~km}^{2}$ and includes the zone where the most population and socioeconomic activities are concentrated. The computation analysis are based on areas zones and faults, each one characterized by recurrence parameters, geometry, minimum and maximum magnitude and source depth. A recent local spectral attenuation model, which includes relations for shallow crustal sources and subduction zone earthquakes, has been applied in this study. The seismic hazard results are presented in terms of contour plots of estimated peak ground acceleration (PGA) for bedrock conditions for return period of 50, 100 and 500 years. In the Central Park of San Jose City the following PGA values were found: $0.29 g$ for 50 years, $0.36 g$ for 100 years, and $0.53 g$ for 500 years. (C) 2000 Elsevier Science Ltd. All rights reserved.
\end{abstract}

Keywords: Shallow seismicity; Seismic hazard analysis; Costa Rican Central Valley

\section{Introduction}

There is evidence of seismic activity in the central part of Costa Rica since historic times $[1,2]$. This activity was first recorded with portable networks [3] and as a result several seismic sources were discovered. However, at that moment it was difficult to locate such seismicity because there were not enough seismic stations in Costa Rica. Furthermore, the seismic stations had an analog recording system that made it difficult to read P and S waves in the seismograms. In 1990 the Red Sismologica Nacional (RSN: ICE-UCR) changed its recording system to a digital one and this, plus the

\footnotetext{
* Corresponding author. Fax: +506-253-2586.

E-mail addresses: mefernan@cariari.ucr.ac.cr (M. Fernández), wrojas@cariari.ucr.ac.cr (W. Rojas).
}

increment in the number of seismic stations, made it possible to locate earthquakes with high accuracy.

On the other hand, faulting of the area has been studied since 1970 when the Geology Department was opened at the University of Costa Rica. During the period 1989-1991, an exhaustive investigation of the faulting of the Central Valley of Costa Rica was carried out as part of a project to mitigate seismic and volcanic risk in that area. Arias and Denyer [4] complemented that investigation by studying the geology in the southern of the valley and finally, Fernandez and Montero [5] applied neotectonic criteria to determine active faults in the area.

The advance in earthquake location and the discovery of active faults in the central part of Costa Rica made it possible to correlate earthquakes and faults and estimate seismic hazard. In this study we carry out this correlation and estimate the seismic hazard for the Metropolitan Area of the Central 
Valley of Costa Rica where the most important cities of the country are located.

\section{Tectonic setting}

Costa Rica is located on the Caribbean plate (Fig. 1) which borders with the Cocos plate along the Middle American Trench. The Cocos plate subducts normally under the Caribbean plate from Guatemala to the Central part of Costa
Rica but this process becomes abnormal in southern Costa Rica where there are no earthquakes below $60 \mathrm{~km}$; these geometric variations are considered as a consequence of different ages of the oceanic crust [6]. In front of the southern Pacific coast of Costa Rica is located the Cocos Ridge which joined the Middle American Trench ca 5 Ma ago [7]. In the Caribbean Sea, in front of the coasts of Costa Rica and Panama, is the North Panama Deformed Belt [8] which is considered as a convergent margin in the Caribbean plate.

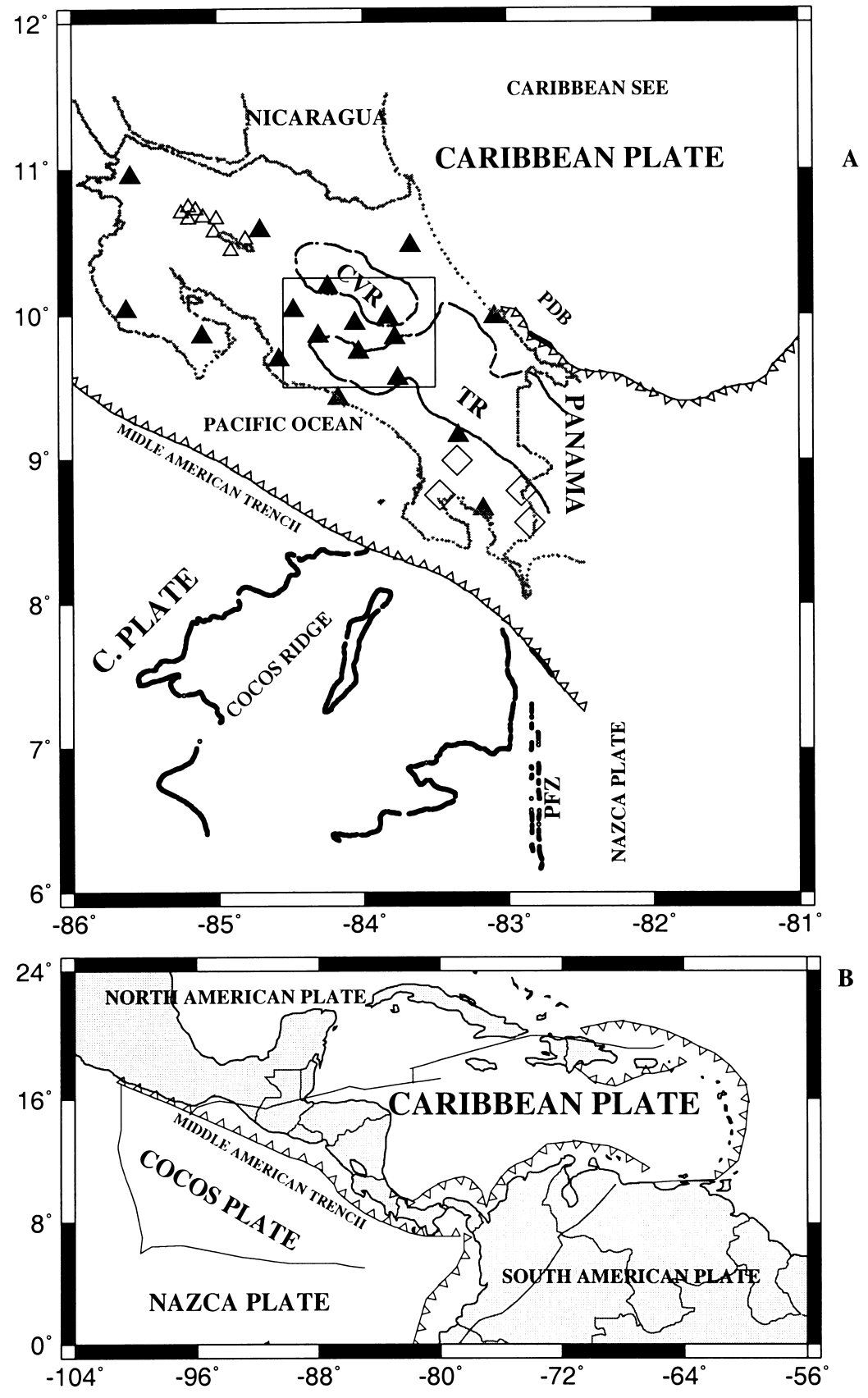

Fig. 1. (A) Local tectonic setting. Costa Rica is located on the western side of the Caribbean plate which borders with Cocos Plate along Middle American Trench. CVR, Central Volcanic Ridge; TR, Talamanca Ridge; PFZ, Panama Fracture Zone; PDB, Panama Deformed Belt. The area of interest is indicated by a rectangle and covers part of the Central Volcanic Ridge of Costa Rica and Talamanca Ridge. Triangles represent seismic stations, black: RSN stations and white (small): Arenal Network. Rhombus are seismic stations of Boruca Network. (B) Regional tectonic setting. 
The Talamanca Ridge and the Central Volcanic Ridge are two important geologic features built by the tectonic activity in Costa Rica. Steep subduction of the Cocos Ridge below southeastern Costa Rica appears to have been responsible for formation of Talamanca Ridge [7] and because of this there is no volcanism in it. The Central Volcanic Ridge was formed by the normal subduction process and has four Quaternary volcanoes.

\section{Data and method}

Earthquakes used in this study are from The National Seismological Network (RSN: ICE-UCR). This network has 17 seismic stations with digital recording, short period and vertical component, distributed all over the country. Eight of these stations are in the studied area and six more near its limits. The RSN locate earthquakes with a unidimensional velocity structure [9] determined by seismic refraction in the north of Costa Rica. The seismic signals analysis was done with the Seisan Earthquake Analysis Software [10,11] which includes a version of the Hypocenter to locate earthquakes. In this study we selected earthquakes with vertical and horizontal errors of location less than $3 \mathrm{~km}$ and with rms equal to 0.5 as maximum. These events were plotted together with the faults in order to determine active faulting.

The methodology used in this study for computation of occurrence of ground motion, as implemented in the program NPRISK [12], requires that the earthquake process can be described as a Poisson process. This requires in turn that the occurrence of events are mutually independent in time and space. Foreshocks and aftershocks were removed from the catalog by the application of a hyperbolic filter as detailed by Camacho et al. [13] and Laporte et al. [14].

In the present study we have used moment magnitudes for all of the events in the catalog, as explained by Rojas et al. [15] and Laporte et al. [14]. We accept the previous Costa Rican catalog completeness tests done by Geomatrix Consultants [16] and Rojas et al. [17], which show completeness for the Central Valley, down to magnitude $2.3\left(M_{\mathrm{w}}\right)$ for the time-window 1980-1996. For seismic zones far from the Central Valley regression analysis indicates catalog completeness from $3.0\left(M_{\mathrm{w}}\right)$ for the timeperiod 1980-1996. For the modeled faults the depth range was set to $0-15 \mathrm{~km}$ in most of the cases. For the Costa Rica territory no evidence is available that indicates deeper crustal faults.

The coordinates $9.86^{\circ} \mathrm{N}-10.00^{\circ} \mathrm{N}$ and $84.18^{\circ} \mathrm{W}-84.01^{\circ} \mathrm{W}$ define the area under focus in this analysis.

\section{Faulting}

According to the distribution of the faults in the study area (Fig. 2), it can be seen that most of the faults follow a NW-SE and NE-SW orientation. This orientation is interpreted by Arias and Denyer [4] to be a consequence of a Miocene-Pliocene compressive phase that affected the Costa Rican territory at that time.

In the Central Volcanic Ridge there are two important fault systems, one that marks the southern limit of the volcanic range and another in the Irazu Volcano (IV) area. The first one is parallel to the strike of the ridge and extends from Irazu to Poas Volcano. The second one is better known, it is a normal fault system which surrounds the Irazu Volcano and has faults no larger than $15 \mathrm{~km}$. Other important faults are Alajuela and Guapiles that according to Borgia et al. [18] and Boschini [19] are reverse faults.

Talamanca Ridge area has a high number of faults suggesting that more deformation has taken place throughout the geological time there. Aguacaliente and HiguitoBelen are well known faults located in the northern flank of Talamanca Ridge, close to the Central Valley. Aguacaliente fault is characterized by the alignment of valleys, hot springs and sulphur mineralizations; Fernandez and Montero [5] considered that this fault is oblique. Higuito-Belen fault has strong changes in slope and scarps and according to Denyer and Arias [20] this fault has vertical displacement (probably reverse displacement); Fernandez and Montero [5] found evidence of reverse displacement in this fault. Most of the other faults are strike-slip.

\section{Seismicity}

\subsection{Historical earthquakes}

There have been eight shallow earthquakes from 1772 to the present in the CVR, seven of them were located in the faulting of Poas Volcano area and one in the northwest flank of Irazu Volcano (Fig. 3). The events of Poas seem to be related to the northwest extreme of the faulting that begins southward Irazu Volcano and ends westward Poas Volcano. Patillos earthquake is a isolated event that has large recurrence periods. Montero and Alvarado [21] indicate that Rio Sucio was the fault responsible for the Patillo earthquake. The main characteristics of these events listed in Table 1.

Southward the Central Valley of Costa Rica, at the Talamanca Ridge side, there have been five important earthquakes since 1834 until the present (Fig. 3), all of them with magnitude larger than 5 . They affected the cities of Cartago and San Jose and killed more than 600 people. The characteristics of those events are listed in Table 2.

All the earthquakes in Table 2 have been located in the faulting close to the southern boundary of the Central Valley, specifically in the segment between Cachi (CA) and San Jose (SJ). They strongly suggest seismic activity along Aguacaliente and Higuito-Belen Faults and this is very important because the cities of Cartago and San Jose, the most important population centers of Costa Rica, are 


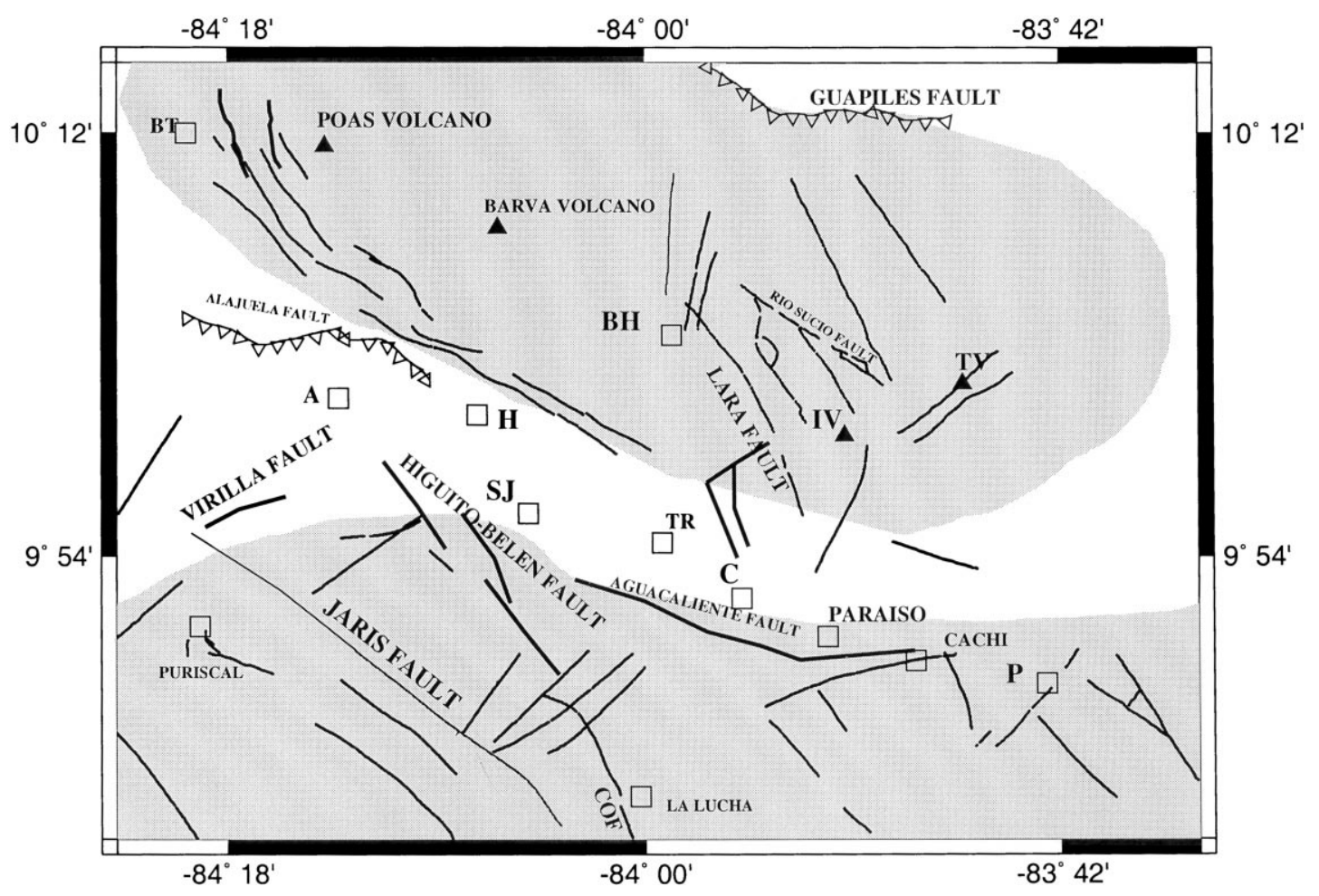

Fig. 2. Structural map of the studied area. Faults were taken from Arias and Denyer [20,36], Denyer and Arias [37,38], Montero et al. [39,40], Montero [41], Denyer et al. [42], Montero and Alvarado [21], Fernández and Montero (in preparation) and Soto [43]. The shadowed areas in the figure correspond to the Talamanca (South) and Central Volcanic (North) Ridges. Black triangles are volcanoes and squares are population centers. BT, Bajos del Toro; BH, Bajo de la Hondura; A, Alajuela; H, Heredia; SJ, San José; TR, Tres Rios; C, Cartago; P, Pejibaye; IV, Irazu Volcano; TV, Turrialba Volcano; COF, Corralillo Fault. Triangles on fault indicate reverse faults, arrows strike-slip faults and \pm normal faults.

close to these seismic sources. In fact, Montero and Morales [22] considered that this is the area of highest seismic risk in the central part of Costa Rica.

\subsection{Instrumental seismicity}

\subsubsection{Central Volcanic Ridge Area}

Forty-six years have passed since the last historic earthquake in the Central Volcanic Ridge (1952) but this fact does not imply absence of seismicity there. On the contrary, there are three seismic foci with permanent seismic activity: the Irazu Volcano Area, Bajo de la Hondura (BH) and the Poas Volcano zone (Fig. 3). Both Irazu and Poas seismic zones have generated destructive earthquakes of moderate magnitude $(M<6.0)$ but, according to the historic seismicity, Poas is the most dangerous seismic source of the Central Volcanic Ridge. In Bajo de la Hondura, the seismic activity is more continuous in time but the magnitude of its earthquakes is smaller than the magnitude of earthquakes from Irazu and Poas. The seismicity of these zones is increased after large earthquakes in the country.

In the Irazu Volcano Area occurred seismic swarms in 1982, 1991 and 1997 [23]; these swarms are composed of thousands of microearthquakes and few earthquakes of magnitude greater than 4 . All of them are due to the faulting around the volcano, specially those located between Irazu and Turrialba volcanoes and southward the crater of Irazu. The seismicity of this zone does not represent a high hazard for the population of the Central Valley, except for earthquakes like Patillos that might produce damage to property. The main consequence of the activity on the faults of this area could be the opening of fractures that may favor an eruption.

There is important seismicity in Bajo de la Hondura where there were seismic swarms in 1978, 1979 and 1980 [21]. The largest earthquakes of these swarms had magnitudes between 3 and 4. In 1990 the largest seismic event of the area occurred, it was an earthquake of magnitude 4.4. That event could be originated in Lara Fault. Lara, Hondura and Patria faults control the seismicity of this area.

At Poas the seismicity is concentrated along the northwest faulting located southward the volcano. Several seismic swarms have originated in this system, the last one being in February of 1997. As in the previous zones, the seismicity increases after large earthquakes here, causing seismic swarms that last one or two days. Also in the trough between the Barva and Poas volcanoes there is seismicity, but in this case there is not clear correlation with faulting.

\subsubsection{Central Valley Area}

The seismicity within the same valley is scarce and scattered (Fig. 3). Some clusters can be observed northward 


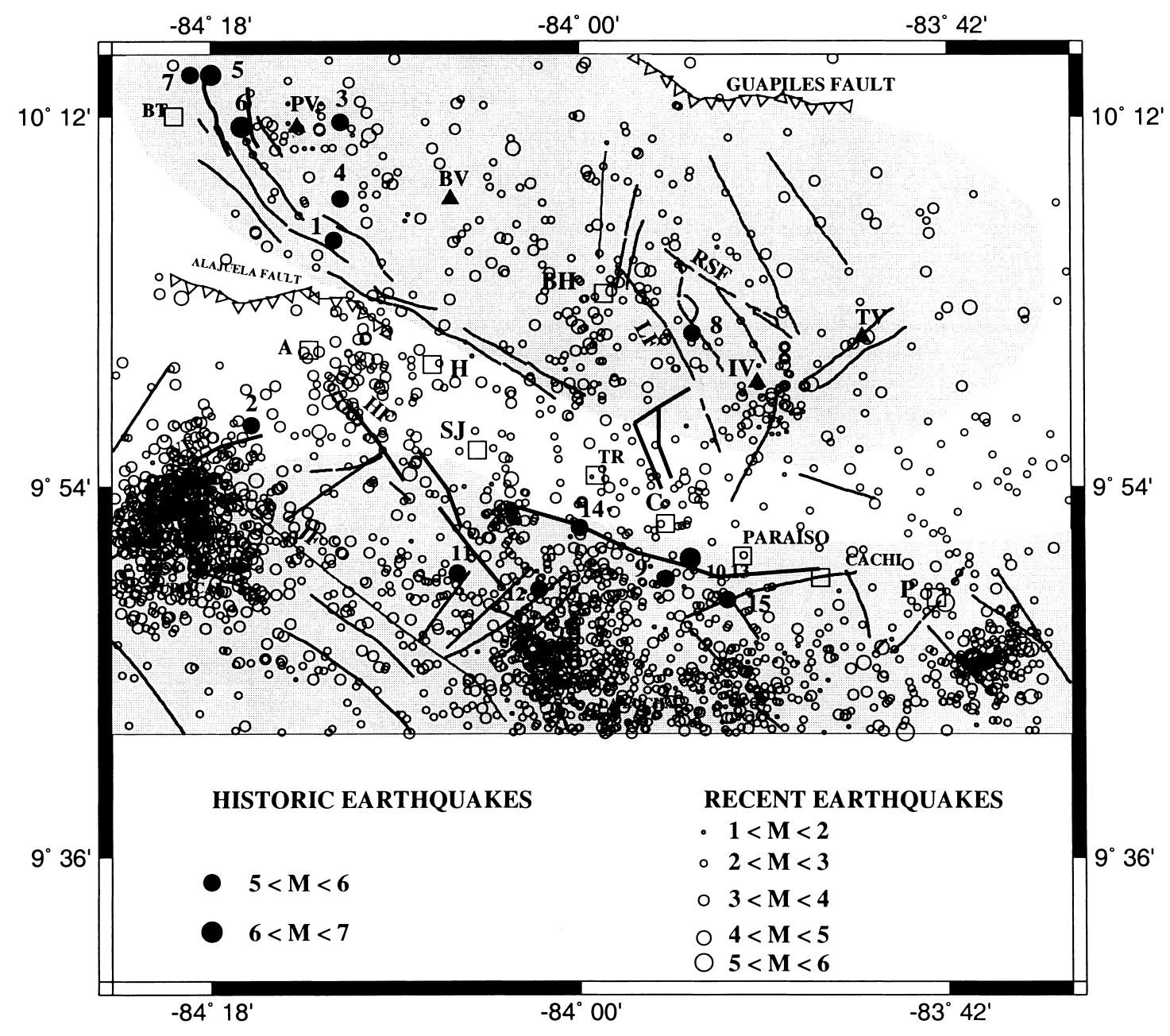

Fig. 3. Seismicity of the studied area. Black circles are historical earthquakes (the number of the earthquake in Tables 1 and 2 has been attached). White circles represent recent earthquakes. Black triangles are volcanoes and squares are population centers. PV, Poas Volcano; BV, Barba Volcano; BH, Bajo de la Hondura; RSF, Rio Sucio Fault; HF, Higuito-Belen Fault; JF, Jaris Fault; LF, Lara Fault.

Cartago (C), southeast of San José (SJ) and near Alajuela (A). It has been difficult to find faults in the Central Valley because most of the surface of this valley is covered by concrete and volcanic deposits. For this reason it is difficult to correlate the seismicity with the faulting here. However, that correlation is clear in Alajuela where Higuito-Belen is the fault responsible for the earthquakes. This structure has been very active during the last 10 years

Table 1

Historic earthquakes in the Central Volcanic Ridge (CVR) [44]

\begin{tabular}{|c|c|c|c|c|}
\hline Number & Name & Year & Magnitude & Damage \\
\hline 1 & Barva Earthquake & 1772 & 5.6 & The earthquake damaged the church of Barba \\
\hline 2 & Alajuela Earthquake & 1835 & 5.8 & Few damage in Alajuela \\
\hline 3 & Fraijanes Earthquake & 1851 & 5.5 & $\begin{array}{l}\text { Important damage in Alajuela, San Jose and } \\
\text { Cartago }\end{array}$ \\
\hline 4 & Fraijanes Earthquake & 1888 & 5.8 & $\begin{array}{l}\text { It affected greatly the cities of Alajuela, Heredia and } \\
\text { San Jose }\end{array}$ \\
\hline 5 & Toro Amarillo Earthquake & 1911 & 6.1 & $\begin{array}{l}\text { Landslides, fracturing of the soil and houses } \\
\text { destruction in Bajos del Toro }\end{array}$ \\
\hline 6 & Sarchi Earthquake & 1912 & 6.2 & Sarchi was severely destroyed, 15 people died \\
\hline 7 & Toro Amarillo Earthquake & 1955 & 5.8 & $\begin{array}{l}\text { Large destruction in Bajos del Toro, evacuation of } \\
\text { that town, } 10 \text { people died }\end{array}$ \\
\hline 8 & Patillos Earthquake & 1952 & 5.5 & $\begin{array}{l}\text { Large damages in the West Flank of Irazu Volcano, } \\
21 \text { people died }\end{array}$ \\
\hline
\end{tabular}


Table 2

Historic earthquakes of Talamanca ridge [44]

\begin{tabular}{|c|c|c|c|c|}
\hline Number & Name & Year & Magnitude & Damage \\
\hline 9 & Cartago Earthquake & 1834 & 5.2 & No damage reported \\
\hline 10 & Cartago Earthquake & 1841 & 5.8 & It was the first destruction of Cartago, 38 people died \\
\hline 11 & Alajuelita Earthquake & 1842 & 5.4 & Damage in Alajuelita \\
\hline 12 & Tablazo Earthquake & 1910 & 5.2 & Damage in San Jose \\
\hline 13 & Cartago Earthquake & 1910 & 6.4 & Severe destruction of Cartago, 600 people died \\
\hline 14 & Tres Rios Earthquake & 1912 & 5.2 & Damage in Tres Ríos \\
\hline 15 & Paraiso Earthquake & 1951 & 5.2 & Paraiso was greatly affected by this event \\
\hline
\end{tabular}

and has produced several seismic swarms southward of San Jose and one in Alajuela. Fortunately, the fault has only originated earthquakes of magnitude less than 5.0. Aguacaliente, a fault that had important activity in the past, now only generates few earthquakes of low magnitude.

\subsubsection{Talamanca Ridge Area}

This is the area with highest level of seismic activity in Central Costa Rica (Fig. 3). Talamanca is a pluton that have been lifting up since Miocene. Earthquakes are distributed all over the area and concentrate in Puriscal, La Lucha, and Pejibaye (Fig. 2).

Puriscal was a very quiet seismic zone but after the Cobano earthquake $\left(M_{\mathrm{s}} 7.1\right)$ on the Pacific Coast in 1990, an intense seismic activity began there; thousands of earthquakes were recorded during the period June-December 1990. Fortunately only 22 of them had magnitudes larger than 4.0 and only one over 5.0. Because of the largest earthquake 3 people died and almost 100 people were injured, it was felt throughout Costa Rica and in western Panama. That seismic activity was produced by activation of small faults of that area.

Pejibaye (P) is a seismic source activated in 1993 where the seismicity is located in a group of northwest faults. The seismic sequence of that year had three important events, an foreshock, the main event and an aftershock. Those earthquakes suggest a fault oriented northwest as most faults. The magnitude of the largest earthquake of that sequence was $5.6 M_{\mathrm{S}}\left(M_{\mathrm{w}}=5.8\right)$ and was felt throughout Costa Rica.

Another important seismic source in the Talamanca Ridge is La Lucha. There is high seismicity northward from that town. In 1991 a $4.7 M_{\mathrm{s}}$ magnitude occurred whose epicenter was located in Corralillo fault as the aftershocks. The main event damaged 30 houses in Cartago area.

\section{Seismic hazard analysis}

This analysis was done for the Metropolitan Area of the Central Valley of Costa Rica and includes shallow subduction zones, shallow crustal sources and local fault systems. Alvarado et al. [24] estimate that a 6.5 magnitude earthquake has a recurrence period of $34 \pm 10$ years in this zone. The $b$-value of 0.96 is one of the highest found in this study, and may indicate that events with magnitudes above 6.5 are unlikely to occur in this zone.

\subsection{Seismic zonation}

The delineation of the seismic area zones were based on a simultaneous analysis and assessment of geology and seismicity, using the following guiding principles: (1) each zone should be large enough to allow for a reasonable stable assessment of the recurrence parameters; (2) the zones cover an area where the earthquake activity has some influence on the seismic hazard of the region under investigation; (3) the zonation does allow for variations in focal depth and tectonic regimes; and (4) the zone definition should be consistent with the geology of the region.

Seismicity source zones were defined at two depth intervals: for shallow subduction zone sources with a depth range from 40 to $200 \mathrm{~km}$, and crustal sources in the depth range down to $39 \mathrm{~km}$. No sources with depths greater than $200 \mathrm{~km}$ were modeled since very few observations at greater depths exist, and since the hazard contribution from greater depths are minor.

Eighteen seismic sources were analyzed and included in the hazard computations for this study. They are divided into three types: four shallow subduction zones, nine crustal shallow seismic zones (Fig. 4, Table 3) and five local fault systems composed of 13 fault segments (Fig. 5 and Table 4).

\subsection{Fault source modeling}

In the estimation of seismic hazard (in the present case using the NPRISK code), the seismic sources are either represented as area sources or fault sources. Different codes are used in the two cases to calculate hazard, even though the two types of sources are similar in the sense that both are described through specific recurrence models or frequency-magnitude distributions, and thereby also specific moment release models.

\subsubsection{Principles and practical approaches}

Various strategies may be chosen for the assessment of earthquake activities on faults, depending on the data available for characterizing the fault movements. There are in principle two viable approaches: (i) in cases where slip rates on faults are directly available procedures based on slip rate 


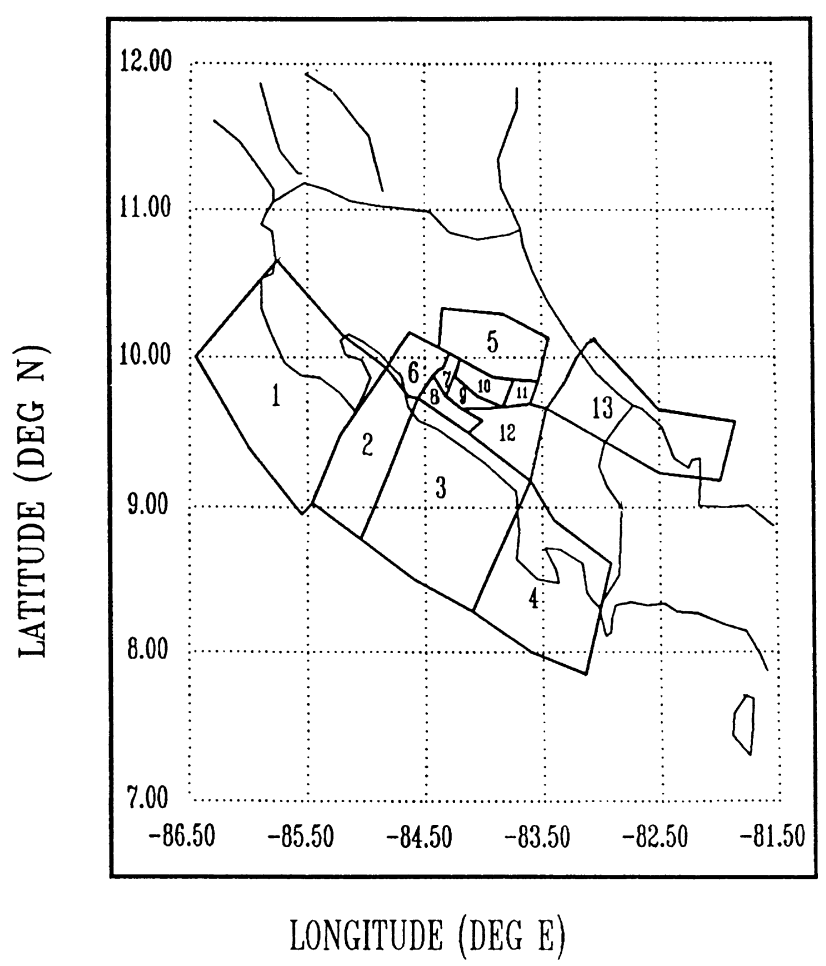

Fig. 4. Shallow area sources used in the hazard computational model.

estimates can be used, preferably in combination with actual activity observations; (ii) when slip rates are not available, the earthquake activity on a fault normally has to be assessed by assigning to the fault a certain part of the seismic activity which is assessed for the region containing the fault, again, if possible, in combination with actual activity observations.

The following principles should be observed in both of these cases: (1) the total seismic activity for a given region predicted by the model should be considered and discussed in details, including its distribution on specific structures, not so much in terms of number of events as in terms of moment (or equivalent, energy) release; (2) there may be important geologic indicators for modeling an (expected) activity level on a fault which is higher than what actually is observed during a period of instrumentation or, for that matter, during the available historical time-period.

When modeling fault activity from slip rates a basic starting point is, as already stated, that the seismicity which is assigned to one individual fault is, as for the area sources, assumed to follow the cumulative Gutenberg-Richter relationship:

$\log N=a-b M$

where $N$ is the cumulative number of earthquakes above magnitude $M$, and $a, b$ are constants. This distribution is limited at the upper end by the maximum magnitude $M_{\max }$ where a sharp cutoff is often assumed, and at the lower end by a limiting or reference magnitude which is the starting point for the seismic hazard integration, essentially determined from engineering considerations. Formally, the cumulative occurrence relationship in this case can be expressed as [25]:

$N_{1}(M)=10^{a(1-b M)} H\left(M_{\max }-M\right)$

where $H(\cdot)$ is the Heavyside step function. This is the Anderson and Luco [26] occurrence relation 1, and it is also the one used in the present study.

Normally, $b$-values for area sources are around 1.0, reflecting a ratio of 10 decrease in the number of events per magnitude unit. The $b$-value assigned to recurrence for faults is often (but not necessarily) lower, however, reflecting the narrower probability density function for magnitudes relating to just one particular fault.

Physically, the reason for the lower values is tied to the concept of "characteristic earthquakes", which is supported theoretically as well as by observational data [27,28]. This concept involves the assumption that most of the energy

Table 3

Seismic activity parameters for the defined area zonation. No., zone number (Fig. 4$)$; $N\left(4.5 M_{\mathrm{w}}\right.$ ), yearly recurrence of magnitude $4.2 M_{\mathrm{w}} ; b$-value, seismicity parameter that describes the relation between the number of small and larger earthquakes; $a$-value, activity rate parameter; Max. Mag., Maximum magnitude; Sd, Source depth. From zone 5, 56\% of the activity has been subtracted, and as detailed below incorporated in the active fault model. Likewise, from zone 7 , $12 \%$ was subtracted, and from zone $10,49 \%$ was subtracted

\begin{tabular}{|c|c|c|c|c|c|c|}
\hline No. & Zone name & $N\left(4.5 M_{\mathrm{w}}\right)$ & $b$-value & $a$-value & $\operatorname{Max}$. Mag. $\left(M_{\mathrm{w}}\right)$ & $\mathrm{Sd}(\mathrm{km})$ \\
\hline 1 & Nicoya Peninsula (subduction) & 2.7542 & 0.88 & 4.40 & 7.7 & $0-40$ \\
\hline 2 & Nicoya Gulf (Subduction) & 1.4125 & 0.74 & 3.48 & 7.1 & $0-40$ \\
\hline 3 & Quepos-Sierpe (Subduction) & 2.4266 & 0.93 & 4.57 & 7.0 & $0-40$ \\
\hline 4 & Osa-Golfito (Subduction) & 2.5409 & 0.71 & 3.60 & 7.3 & $0-40$ \\
\hline 5 & North of Central Valley & 0.1241 & 0.96 & 3.77 & 6.5 & $2-15$ \\
\hline 6 & Tarcoles-Barranca & 0.2065 & 0.61 & 2.06 & 7.0 & $2-15$ \\
\hline 7 & Puriscal-Virilla & 0.4953 & 0.78 & 3.26 & 6.1 & $2-15$ \\
\hline 8 & Candelaria & 0.1798 & 0.85 & 3.08 & 7.0 & $2-15$ \\
\hline 9 & Jaris-Corralillo & 0.2065 & 0.83 & 3.05 & 6.8 & $2-15$ \\
\hline 10 & Escazú-Guarco & 0.0865 & 0.83 & 3.31 & 6.5 & $1-15$ \\
\hline 11 & Turrialba-Atirro & 0.1758 & 0.63 & 2.08 & 6.5 & $2-15$ \\
\hline 12 & Perez Zeledon & 1.2735 & 0.83 & 3.80 & 6.2 & $4-15$ \\
\hline 13 & Limon-Changuinola & 1.9054 & 0.74 & 3.61 & 7.7 & $5-25$ \\
\hline
\end{tabular}




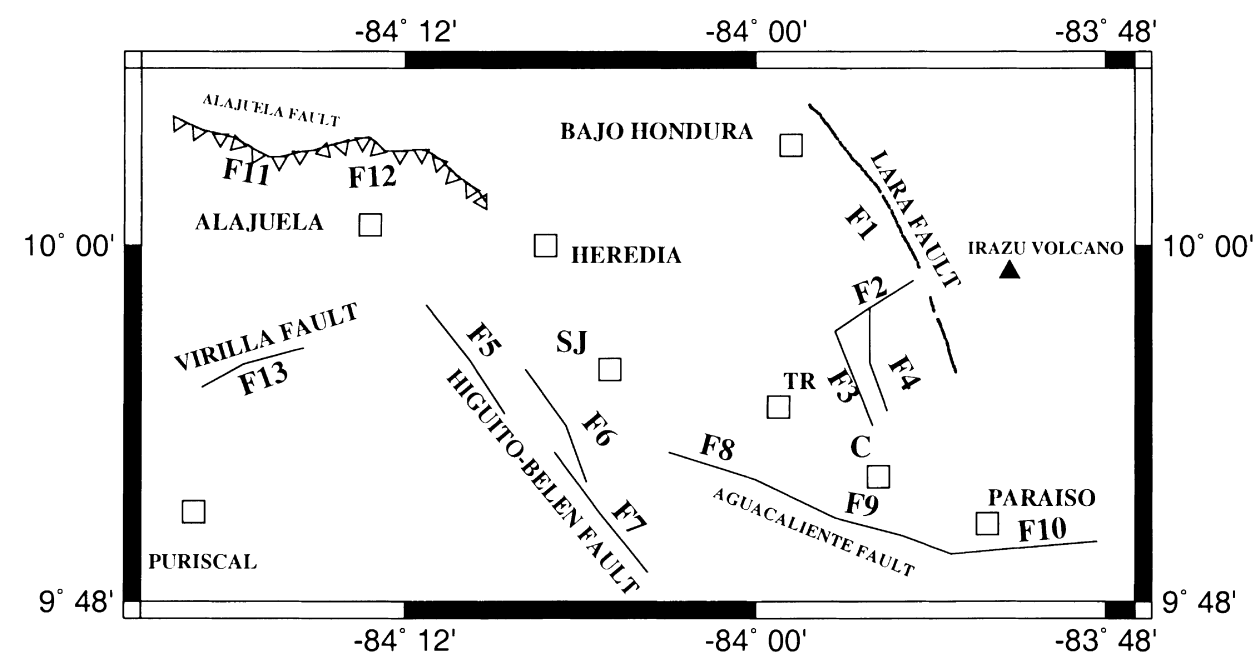

Fig. 5. Active and better known faults in Central Valley, Costa Rica. F1-F13 fault segments were modeled in the hazard analysis.

released (or slip) on a fault is accounted for through earthquakes with a larger value regionally (in modeling area sources) where the contribution from a variety of faults, large and small, is considered.

The estimation of activity rates ( $N$-values) involves also the seismic moment, $M_{0}$, the rigidity modulus, $\mu$, the displacement per length of rupture area, $\alpha$, and the rupture area, $A=L W$, where $L$ is the fault length and $W$ the fault width. The seismic moment for a particular earthquake is physically defined as

$M_{0}=\mu D A$

where $D$ is the total average displacement (slip) across the fault.

Assuming conservatively that all of the fault slip occurs seismically, the total moment release rate (such as moment per year) $M_{0}^{\mathrm{T}}$ is related to the slip rate (fault movement per year) of the fault as follows $[26,29]$ :

$M_{0}^{\mathrm{T}}=\mu S A$

where $\mu$ is the rock shear modulus and $S$ is the annual slip (slip rate). It has been suggested that $M_{0}$ must be averaged over several cycles of large earthquakes for this relation to be valid [30].

Based on Eqs. (1) and (3), Anderson and Luco [26] deduced the following relationship for the determination

Table 4

Characteristics of the five main fault systems analyzed in this study

\begin{tabular}{llrll}
\hline Name & Type & Dip & $\begin{array}{l}\text { Segments } \\
\text { (Fig. 4) }\end{array}$ & $\begin{array}{l}\text { Length } \\
(\mathrm{km})\end{array}$ \\
\hline Lara & Strike-slip & $80-85$ & 4 (F1, F2, F3, F4) & 27 \\
Higuito-Belen & Oblique & 80 & (F5, F6, F7) & 30 \\
Aguacaliente & Oblique & $75-80$ & 3 (F8, F9, F10) & 37 \\
Alajuela & Reverse & 35 & 2(F11, F12) & 28 \\
Virilla & Strike-slip & 90 & 1 (F13) & 8 \\
\hline
\end{tabular}

of the number of earthquakes $N$ above the threshold magnitude (normally around magnitude 4-5) on a fault:

$N=\left(\frac{\bar{d}-\bar{b}}{\bar{d}}\right)\left(\frac{S}{\beta}\right) \mathrm{e}^{\bar{b}\left(M_{\max }-M\right)} \mathrm{e}^{(\bar{d} / 2) M_{\max }}$

where $\bar{d}=d(\ln (10)), \bar{b}=b(\ln (10)), \beta=\sqrt{\left(\alpha M_{0}(0)\right) /(\mu W)}$ and $M_{0}(0)$ is the seismic moment for $M_{\mathrm{s}}=0$. The parameter $d$ is the magnitude scaling coefficient in the relation between moment and magnitude of the form $\log M_{0}=c-d M$.

A computer (utility) program "mom_slip" has been developed at NORSAR (Hilmar Bungum, personal commun.) which offers this occurrence model together with four other models [31], where the difference is mostly on how the recurrence model tapers off towards the maximum magnitude. The parameterization used in this program is as follows: model to use (one of five available), slip rate in $\mathrm{mm} / \mathrm{yr}$, fault length range ( $\mathrm{min} / \mathrm{max} / \mathrm{increment})$ in $\mathrm{km}, b$ value in $\log N=a-b M$, magnitude for $N$-value calculation, magnitude type $\left(M_{\mathrm{w}}, M_{\mathrm{s}}\right.$ or user-defined), momentmagnitude relation: $\log M_{0}=c+d M$, fault area-maximum magnitude relation: $\log A_{\mathrm{f}}=a+b M_{\max }$, slip/fault length (aspect) ratio, fault length/width factor $(\alpha)$ and shear modulus $(\mu)$.

It should be noted here that when a magnitude scale other than $M_{\mathrm{w}}$ is used, relations to $M_{\mathrm{w}}$ are established either through a user-defined moment-magnitude relation combined with the Hanks and Kanamori [32] $M_{0}-M_{\mathrm{w}}$ relation, or through a standard (global) $M_{\mathrm{w}}-M_{\mathrm{s}}$ relation when $M_{\mathrm{s}}$ is used [33].

When slip-rate estimates are not available the seismic activity on faults is normally estimated on the basis of the area source seismicity in the region, as deduced from the historical and the recent seismicity. This can conveniently be done for example by assigning a certain percentage of the seismicity to the faults, keeping the remaining for the area source(s) containing the faults. This percentage can be 
applied directly to the $N$-values if the $b$-values are the same for area and fault sources, but if the $b$-values are different the percentage has to be applied to the moment release, inferring $a$ - or $N$-values indirectly.

This can be done using another utility program ("mom_rate") also developed at NORSAR, with a parameterization as follows: reference magnitude for $N$, area zone $N, b$, and $M_{\max }$, fault zone $M_{0}$-fraction and $M_{\max }$, momentmagnitude relation: $\log M_{0}=c+d M$, fault length in $\mathrm{km}$ and fault length/width factor, $a$-value iteration steps and moment ratio convergence limit, max no. of iterations and level $(2,1$ or 0$)$ of output details.

In cases when the $b$-values and/or the maximum magnitudes are different it becomes particularly important to use an approach of the present kind. The ruling principle in all of this is, in fact, that it is the seismic moment budget which is the main scaling parameter, facilitated by the availability of appropriate moment-magnitude relationships.

\subsubsection{Parameterization}

For the present fault analysis and its integration in the NPRISK analysis, the basic and necessary data are presented in Table 5. In the basic approach available empirical data (both on moment release and slip) has been used in constraining the numerical models. The "mom_slip" program allows different $b$-values for areas sources and faults, so we have chosen to use the area source values (as estimated from the earthquake catalog) for the faults.

Slip rates are also tested through a combination of structural geological indicators and specific displacement observations for individual events to be about $5 \mathrm{~mm} / \mathrm{yr}$ (Montero, personal commun.). The slip/fault length value has been set to $4.5 \times 10^{-5}$, obtained from observed earthquake slip and fault lengths in the region.

According to the models proposed by Anderson and
Luco [26], their model number 1 was found to be the most appropriate for the faults considered in this study. That model yields the most consistent $N$-values for an expected recurrence about every 400 years of an $M_{\mathrm{w}}$ 6.0-6.5 earthquake, and more than 500 years for up to $M_{\mathrm{w}}$ 7.0 .

\subsubsection{Fault moment (energy) contributions}

The results of such an analysis of fault activities for the present situation are shown in Table 6. The analysis is done for North of Central Valley, where the North of Central Valley seismic zone contains the Alajuela and the Lara fault system, and for the South of Central Valley, where the Virilla, Higuito-Belen and Aguacaliente faults are.

As seen, we found differences in the moment release generated from individual earthquake sources (seismic zones and faults) and the moment generated by the region considered as a whole.

We found that the active faults included in the model contribute with about half of the shallow crustal energy for the studied region. The other half would be coming from sources not yet classified in terms of active faults. For computational purposes for the seismic hazard estimation, we need to subtract the energy contribution from the faults from the total energy released from seismic zones containing these faults. This subtraction is done because if it is not done, the seismic hazard could be overestimated.

We have found here that the moment release ascribed to the faults therefore contributes with about $50 \%$ of the expected total moment release within the Central Valley region. If we consider a fault segment of about $9 \mathrm{~km}$ length this would correspond to a maximum earthquake of about $M_{\mathrm{w}} 6.0$ (the $M_{\mathrm{w}} 6.0$ Virilla fault rupture on 22/12/90 had a fault length of $8 \mathrm{~km}$ ). We find by summing all active faults

Table 5

Main parameters for the faults modeled in the hazard analysis. F.Syst. $=$ fault system; F.Seg $=$ fault segment; HD $=$ horizontal distance of surface fault projection in $\mathrm{km} ; N(4.2)=$ yearly recurrence of $M_{\mathrm{w}} 4.2 ; b=$ index of seismicity; FL = fault length in $\mathrm{km} ; \mathrm{FD}=$ fault depth; F.Dip = fault dip in degrees, Max. $M_{\mathrm{w}}=$ maximum moment magnitude; $\mathrm{Sr}=$ slip rate in $\mathrm{mm} / \mathrm{year}, \mu=$ shear module in $\mathrm{g} / \mathrm{cm} \mathrm{s}^{2} ; \mathrm{Rec}=$ earthquake recurrence in years for $M_{\mathrm{w}} 6.0$ and 6.5

\begin{tabular}{|c|c|c|c|c|c|c|c|c|c|c|c|}
\hline F.Syst. & F.Seg & $\mathrm{HD}(\mathrm{km})$ & $N(4.2)$ & $b$ & $\mathrm{FL}(\mathrm{km})$ & $\mathrm{FD}(\mathrm{km})$ & F.Dip & $\operatorname{Max} M_{\mathrm{w}}$ & $\mathrm{Sr}(\mathrm{mm} / \mathrm{yr})$ & $\mu$ & Rec. $6.0-6.5$ (yr) \\
\hline Lara & $\begin{array}{l}1 \text { A Lara } \\
2 \text { B Rancho } \\
3 \text { C Dorita } \\
\text { 4 D Laguna }\end{array}$ & $\begin{array}{l}2.6 \\
1.3 \\
1.3 \\
1.3\end{array}$ & $\begin{array}{l}0.0854 \\
0.0782 \\
0.0854 \\
0.0854\end{array}$ & $\begin{array}{l}0.83 \\
0.83 \\
0.83 \\
0.83\end{array}$ & $\begin{array}{l}18 \\
08 \\
09 \\
09\end{array}$ & $\begin{array}{l}15 \\
15 \\
15 \\
15\end{array}$ & $\begin{array}{l}80^{\circ} \mathrm{SW} \\
85^{\circ} \mathrm{NW} \\
85^{\circ} \mathrm{SW} \\
85^{\circ} \mathrm{SW}\end{array}$ & $\begin{array}{l}6.3 \\
5.8 \\
6.0 \\
6.0\end{array}$ & $\begin{array}{l}4.0 \\
4.0 \\
4.0 \\
4.0\end{array}$ & $\begin{array}{l}0.197 \times 10^{12} \\
0.197 \times 10^{12} \\
0.197 \times 10^{12} \\
0.197 \times 10^{12}\end{array}$ & $371-950$ \\
\hline Higuito-Belen & $\begin{array}{l}5 \text { A Escazu } \\
6 \text { B Alajuelita } \\
7 \text { C Aserri }\end{array}$ & $\begin{array}{l}2.63 \\
00 \\
2.6\end{array}$ & $\begin{array}{l}0.1023 \\
0.1023 \\
0.1023\end{array}$ & $\begin{array}{l}0.83 \\
0.83 \\
0.83\end{array}$ & $\begin{array}{l}10 \\
09 \\
11\end{array}$ & $\begin{array}{l}15 \\
12 \\
15\end{array}$ & $\begin{array}{r}80^{\circ} \mathrm{NE} \\
\text { Vertical } \\
80^{\circ} \mathrm{NE}\end{array}$ & $\begin{array}{l}5.8 \\
5.8 \\
5.8\end{array}$ & $\begin{array}{l}4.0 \\
4.0 \\
4.0\end{array}$ & $\begin{array}{l}0.283 \times 10^{12} \\
0.283 \times 10^{12} \\
0.283 \times 10^{12}\end{array}$ & 310 \\
\hline Aguacaliente & $\begin{array}{l}8 \text { A Tablazo } \\
9 \text { B Coris } \\
10 \text { C Paraiso }\end{array}$ & $\begin{array}{l}2.11 \\
2.6 \\
4.02\end{array}$ & $\begin{array}{l}0.1023 \\
0.1186 \\
0.1186\end{array}$ & $\begin{array}{l}0.83 \\
0.83 \\
0.83\end{array}$ & $\begin{array}{l}08 \\
12 \\
18\end{array}$ & $\begin{array}{l}12 \\
15 \\
15\end{array}$ & $\begin{array}{l}80^{\circ} \mathrm{NE} \\
80^{\circ} \mathrm{NE} \\
75^{\circ} \mathrm{NE}\end{array}$ & $\begin{array}{l}5.5 \\
6.2 \\
6.3\end{array}$ & $\begin{array}{l}4.0 \\
4.0 \\
4.0\end{array}$ & $\begin{array}{l}0.283 \times 10^{12} \\
0.283 \times 10^{12} \\
0.283 \times 10^{12}\end{array}$ & $260-683$ \\
\hline Alajuela & $\begin{array}{l}11 \text { A Grecia } \\
12 \text { B Itiquis }\end{array}$ & $\begin{array}{l}14.0 \\
12.8\end{array}$ & $\begin{array}{l}0.1186 \\
0.1186\end{array}$ & $\begin{array}{l}0.83 \\
0.83\end{array}$ & $\begin{array}{l}11 \\
17\end{array}$ & $\begin{array}{l}12 \\
12\end{array}$ & $\begin{array}{l}35^{\circ} \mathrm{N} \\
40^{\circ} \mathrm{N}\end{array}$ & $\begin{array}{l}6.0 \\
6.2\end{array}$ & $\begin{array}{l}4.0 \\
4.0\end{array}$ & $\begin{array}{l}0.197 \times 10^{12} \\
0.197 \times 10^{12}\end{array}$ & $260-683$ \\
\hline Virilla & 13 A Virilla & 1.76 & 0.0775 & 0.73 & 08 & 10 & Vertical & 6.0 & 4.0 & $0.283 \times 10^{12}$ & 330 \\
\hline
\end{tabular}


Table 6

Moment release of the seismic sources. For the area zones the moment release was obtained from the seismicity catalogs, whereas the moment release for faults was modeled with basis in observed fault dimensions and slip rates. ZMR $=$ zone moment release in dyn $/ \mathrm{cm}^{2} ; \mathrm{CV}=\mathrm{Central} \mathrm{Valley;} \mathrm{ZE}=$ percentage of zone energy contribution; F. Syst $=$ fault system name; F.Mo.R $=$ fault moment release in dyn $/ \mathrm{cm}^{2} ; \mathrm{FE}=$ percentage of fault energy contribution relative to area energy contribution $(\%)$ FET $=$ percentage of fault energy contribution for the region $(\%)$

\begin{tabular}{|c|c|c|c|c|c|c|}
\hline Seismic zone & $\mathrm{ZMR}\left(\mathrm{dyn} / \mathrm{cm}^{2}\right)$ & $\mathrm{ZE}(\%)$ & F. Syst. & F.Mo.R $\left(\mathrm{dyn} / \mathrm{cm}^{2}\right)$ & $\mathrm{FE}(\%)$ & FET $(\%)$ \\
\hline North of CV & $0.190 \times 10^{24}$ & 22 & $\begin{array}{l}\text { Alajuela } \\
\text { Lara }\end{array}$ & $\begin{array}{l}0.442 \times 10^{23} \\
0.625 \times 10^{23}\end{array}$ & $\begin{array}{l}6 \\
8\end{array}$ & 56 \\
\hline South of C.V. & $0.335 \times 10^{24}$ & 37 & Virilla & $0.362 \times 10^{23}$ & 5 & 11 \\
\hline $\begin{array}{l}\text { Higuito-Belen } \\
\text { Aguacaliente }\end{array}$ & $0.356 \times 10^{24}$ & 41 & $\begin{array}{l}\text { Higuito-Belen } \\
\text { Aguacaliente }\end{array}$ & $\begin{array}{l}0.987 \times 10^{23} \\
0.770 \times 10^{23}\end{array}$ & $\begin{array}{l}12 \\
20\end{array}$ & 77 \\
\hline Total & $0.880 \times 10^{24}$ & 100 & Total & $0.418 \times 10^{24}$ & 51 & \\
\hline
\end{tabular}

contributions from Table 5 that a total length of $160 \mathrm{~km}$ would be needed, divided into 17 fault segments each of $9 \mathrm{~km}$ length. Taken together, this would correspond to a return (recurrence) time of about 90 years for $M_{\mathrm{w}} 6.0$.

However, since a similar amount of energy release is modeled to come from faults not yet specifically identified, we find that this will reduce the recurrence time to about 40 years for $M_{\mathrm{w}} 6.0$, in close correspondence with the historical records.

\section{Seismic hazard assessment for a selected zone}

Seismic hazard was computed in terms of PGA for the Central Valley Area. The results are presented below in terms of smoothed PGA maps for the Central Valley microzonation area. The PGA contour maps for annual exceedance probabilities $2 \times 10^{-2}, 10^{-2}$ and $2 \times 10^{-3}$ are presented in Figs. 6-8, respectively.

For all of three annual probabilities, the results show a southwest variation in the area studied. In the case of $10^{-2}$, the PGA increases from around $3.2 \mathrm{~m} / \mathrm{s}^{2}$ in the northern part to about $3.75 \mathrm{~m} / \mathrm{s}^{2}$ in the southern part. The phenomena responsible for the higher PGA values in southern San Jose are the high activity rates on the seismic zones in the area, together with the active faults modeled.

In addition to the zonation in a grid, PGA has also been computed for the Central Park in San Jose city. The results are for bedrock conditions and annual exceedance probabilities corresponding to return periods of 10,25 , 50, 100 and 500 years (Table 7). Therefore the value for a 100 years return period is $30 \%$ higher than

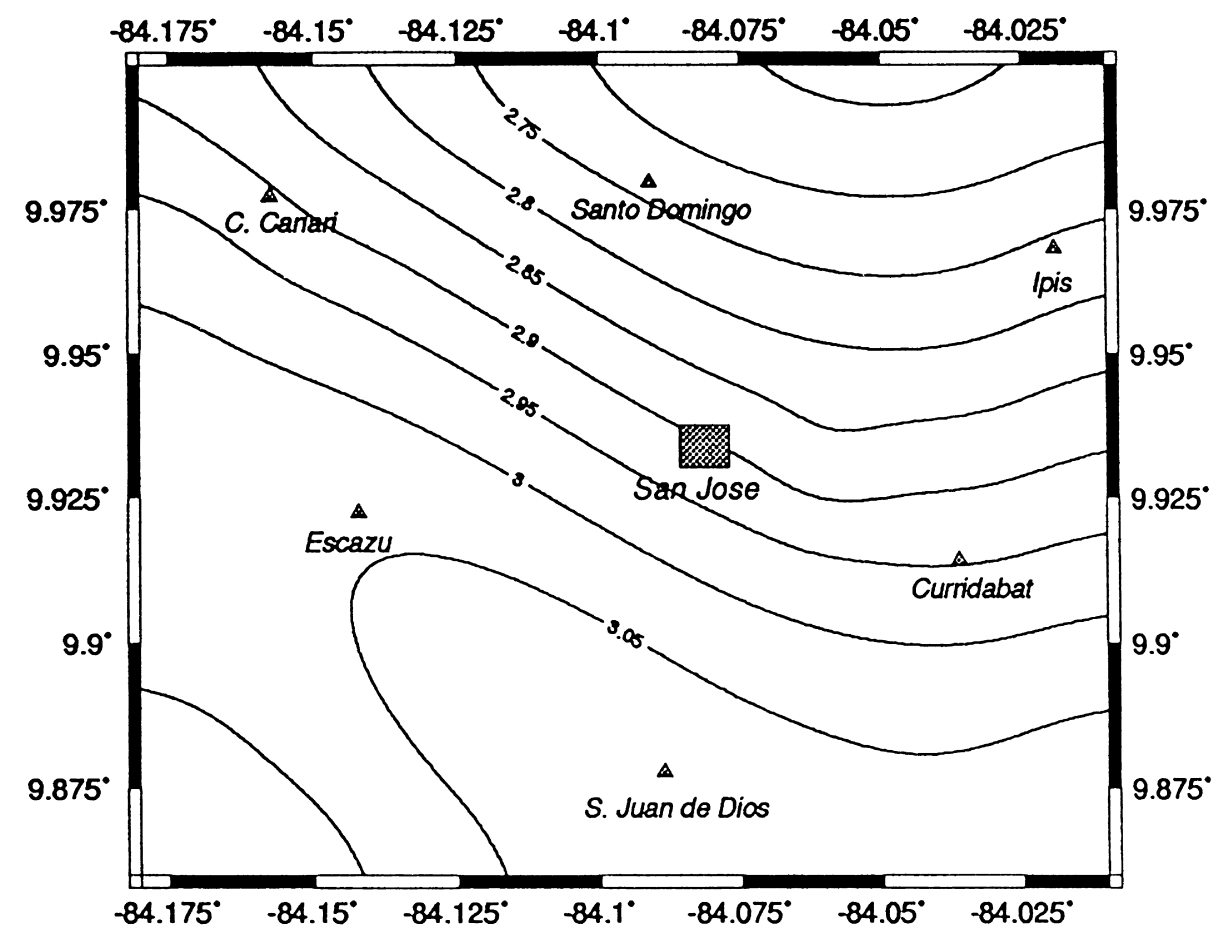

Fig. 6. Expected PGA $\left(\mathrm{m} / \mathrm{s}^{2}\right)$ for the Central Valley microzonation area. Isolines represent PGA at the annual exceedance probability of $2 \times 10^{-2}$. 


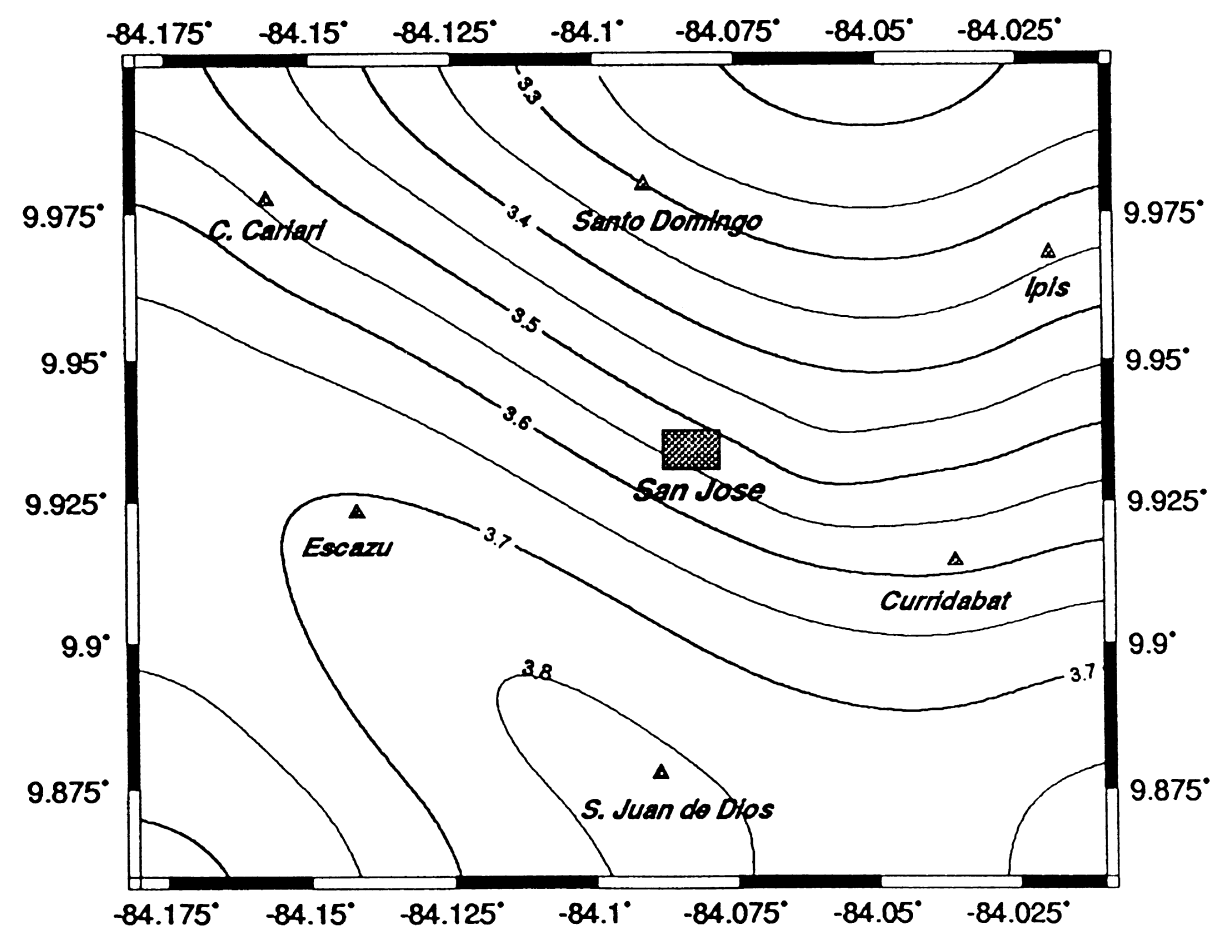

Fig. 7. Expected PGA $\left(\mathrm{m} / \mathrm{s}^{2}\right)$ for the Central Valley microzonation area. Isolines represent equal PGA values at the annual exceedance probability of $10^{-2}$.

previously obtained at bedrock level for San Jose city by Laporte et al [14]. The main reason for that increment is; the usage of new attenuation relation of Schmidt et al. [34], more local seismicity data up to $2.3 M_{\mathrm{L}}$, the local seismotectonic model and the inclusion and use of active faults in the model.

Since all the input model parameters were provided with a central value and lower and higher extreme values with

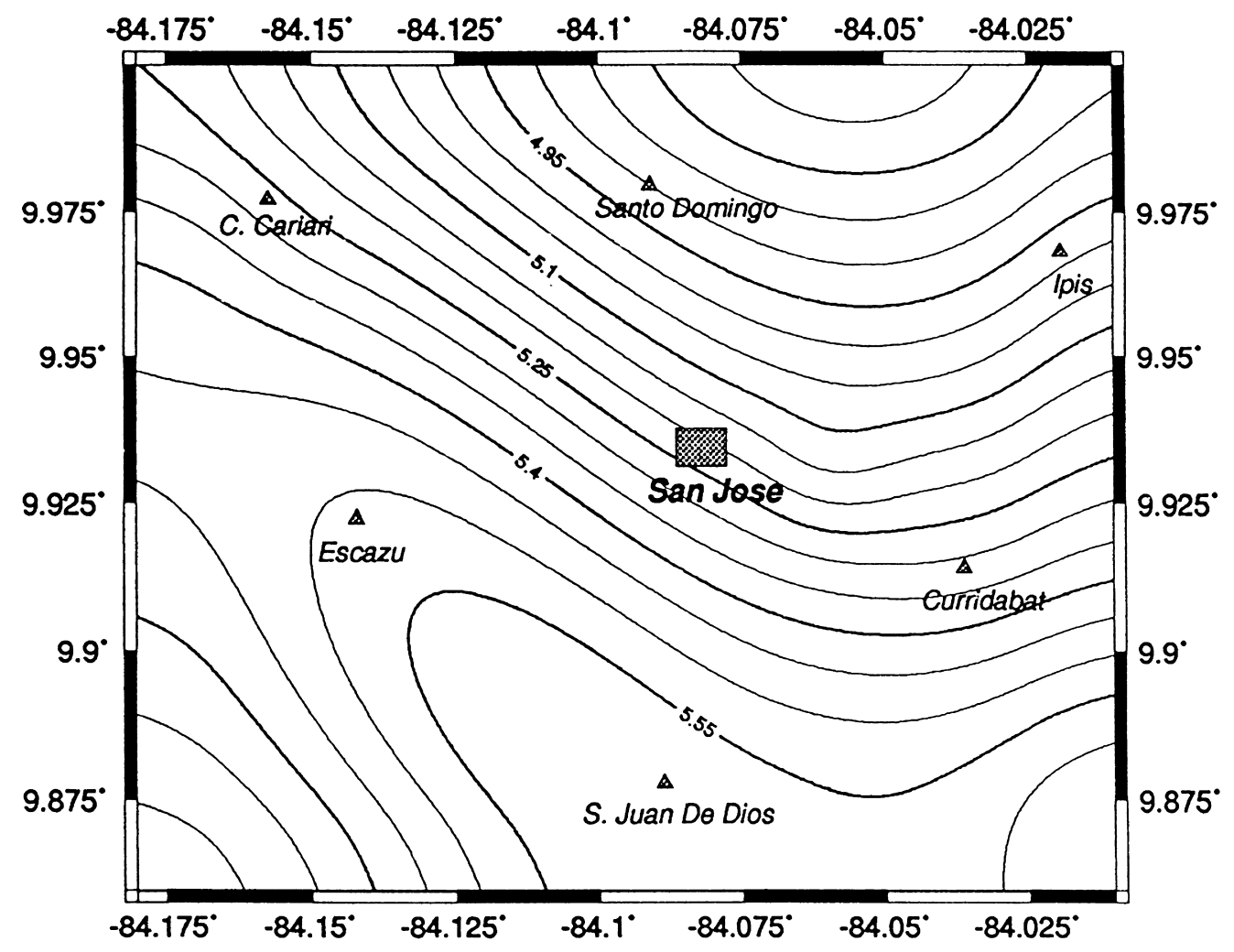

Fig. 8. Expected PGA $\left(\mathrm{m} / \mathrm{s}^{2}\right)$ for the Central Valley microzonation area. Isolines represent equal PGA values at the annual exceedance probability of $2 \times 10^{-3}$. 
Table 7

PGA $\left(\mathrm{m} / \mathrm{s}^{2}\right)$ results for Central Park of San Jose City

\begin{tabular}{ll}
\hline $\begin{array}{l}\text { Return period } \\
(\mathrm{yr})\end{array}$ & $\begin{array}{l}\text { Bed rock maximum } \\
\text { acceleration }\left(\mathrm{m} / \mathrm{s}^{2}\right)\end{array}$ \\
\hline 10 & 1.779 \\
25 & 2.387 \\
50 & 2.894 \\
100 & 3.508 \\
500 & 5.184 \\
\hline
\end{tabular}

assigned probabilities (logic tree), the confidence limits could be computed along with the expected values. The parameter ranges are given below.

$b$-value; center value \pm 0.15 ; with weights of $0.3,0.4$ and 0.3

$\mathrm{N}$-value; divided and multiplied with 2.0; with weights of $0.3,0.4$ and 0.3

Max. magnitude; center value $-0.3 /+0.2$; with weights of $0.25,0.5$ and 0.25

Depths; center value $-0.3 /+0.2$; with weights of $0.3,0.4$ and 0.3 .

Fig. 9 shows the hazard curve for PGA in $\mathrm{cm} / \mathrm{s}^{2}$ with 16 and $84 \%$ fractiles (corresponding to $\pm 1 \sigma$ ).

\subsection{Sensitivity of the seismic hazard input parameters}

The sensitivity of the results to selected parameters in the computational model was tested for the Cartago city site.

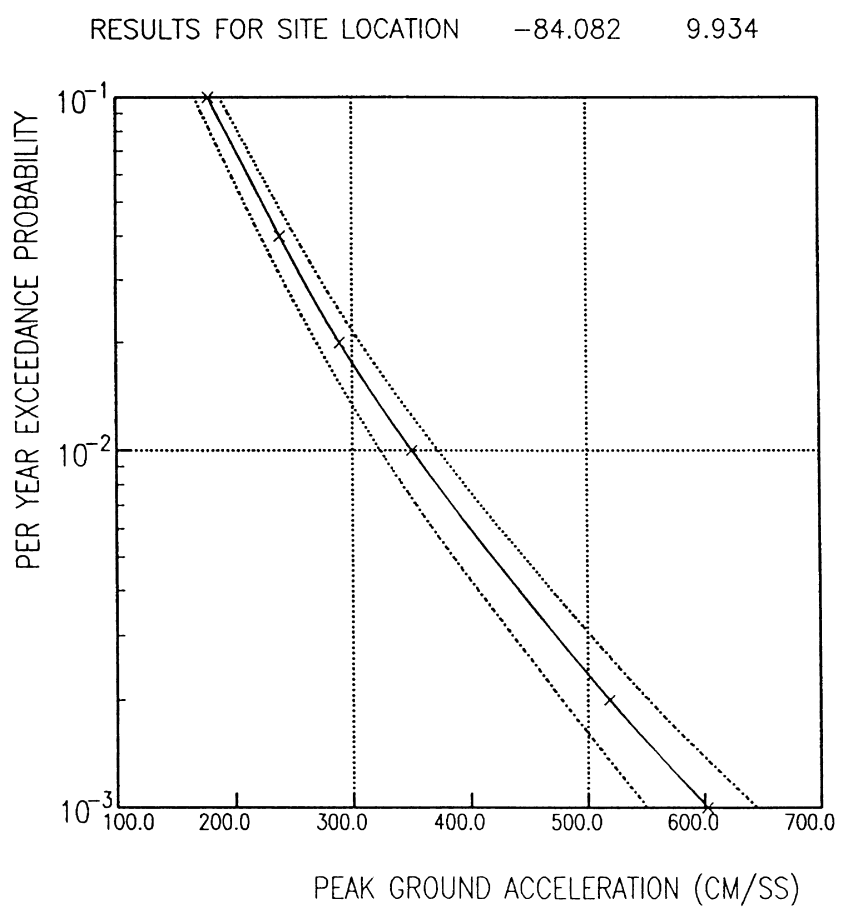

Fig. 9. PGA hazard curve (expected $\pm 1 \sigma$ ) for San Jose. Values are calculated for hard rock sites.
The test was done for the Cartago city site with hazard contributions only from the seismicity zone in which Cartago is located and only from one fault (the nearest Aguacaliente fault). The testing consisted of computing the hazard based on the correct parameter values, and then introducing variation in one parameter to observe the change in the PGA results. For example, the results when the $N$-values were reduced by $50 \%$ were compared with results from full $N$-values etc. Table 8 summarizes this sensitivity.

This indicated that the right parameters $(N, b$, focal depth, $M_{\max }$ and $\left.M_{\min }\right)$ are crucial because a wrong parameters estimate may significantly change the result. It should be noted that another parameter of vital importance is the $\sigma$ value (scatter value) in the attenuation relation. For $\ln$ (PGA), values between 0.5 and 0.7 have been used here, in accordance to Schmidt et al. [34].

\subsection{Ground motion response spectra}

Equal hazard ground motion response spectra were developed at $5 \%$ damping for San Jose for annual exceedance probabilities of $10^{-2}, 2 \times 10^{-2}$ and $2 \times 10^{-3}$. The approach for developing pseudo-relative velocity (PSV) response spectra was to compute PSV spectral ordinates for the frequencies of $0.25,0.50,1.0,2.0,5.0,10.0 \mathrm{~Hz}$, and for peak ground acceleration (PGA) defined at $40 \mathrm{~Hz}$. The resulting absolute PSV values for annual exceedance probability of $10^{-2}, 2 \times 10^{-2}$ and $2 \times 10^{-3}$ at $5 \%$ damping are shown in Table 9 and the spectrum is shown in Fig. 10.

For hard- and soft-soil site conditions the absolute spectra as well as PGA may be obtained by multiplying the rock site spectral ordinates with appropriate amplification factors. These factors may vary significantly over the Central Valley region, and are investigated in a study parallel to the present one.

In the study by Laporte et al. [14], the equal hazard spectrum for a San Jose soil site for return periods of 50, 100, 500 and 1000 years was done. All of the spectra of Laporte et al. [14] peak around $1 \mathrm{~Hz}$, in contrast to the present results that peak around $2 \mathrm{~Hz}$. Again, the main reason for this difference is that while Laporte et al. [14] have used an attenuation relation estimated for all Central America [35], in this study we have used an attenuation relation estimated for Costa Rica alone [34]. In addition to that, we are using an updated version of the catalog used by

Table 8

Sensitivity of results to selected input parameters in the model

\begin{tabular}{llll}
\hline Parameter & Variation & PGA $\left(\mathrm{m} / \mathrm{s}^{2}\right)$ & Contribution $(\%)$ \\
\hline Target PGA & None & 2.97 & \\
$N$ & $N-N / 2$ & 2.19 & 26 \\
$b$ & $b-0.20 b$ & 3.11 & 5 \\
Depth & $h+h / 2$ & 2.41 & 17 \\
Minimum Mag & $M_{\min }+0.3$ & 3.41 & 14 \\
Maximum Mag & $M_{\max }-0.3$ & 2.4 & 12 \\
\hline
\end{tabular}


Table 9

Absolute PSV spectral ordinates $(\mathrm{m} / \mathrm{s})$, for bedrock condition, at annual exceedance probabilities $2 \times 10^{-2}, 10^{-2}$ and $2 \times 10^{-3}$ for the city of San Jose at $5 \%$ damping

\begin{tabular}{llll}
\hline Frequency $(\mathrm{Hz})$ & \multicolumn{2}{l}{ Annual exceedance probability } \\
\cline { 2 - 4 } & $2 \times 10^{-2}$ & $10^{-2}$ & $2 \times 10^{-3}$ \\
\hline 0.25 & 0.092750 & 0.113430 & 0.174140 \\
0.50 & 0.162380 & 0.196909 & 0.306541 \\
1.00 & 0.182501 & 0.223179 & 0.344351 \\
2.00 & 0.225211 & 0.277749 & 0.416101 \\
5.00 & 0.164340 & 0.195739 & 0.293761 \\
10.0 & 0.077440 & 0.092030 & 0.137360 \\
40.0 & 0.011522 & 0.013964 & 0.020636 \\
\hline
\end{tabular}

Laporte et al. [14] which comprises small earthquakes (2.3 and above) and a new seismotectonic model that includes active faults.

Normalized ground motion response spectra at 5\% damping were developed from the average San Jose spectrum. These normalized spectra are evaluated to be representative for hard rock sites in the Central Valley region and are listed in Table 10 and shown in Fig. 11.

\section{Conclusions}

In the Central Part of Costa Rica the faulting has two predominant orientations: northwest and northeast. Large

\section{San Jose site PSV for return periods of 50,100 and 500 years}

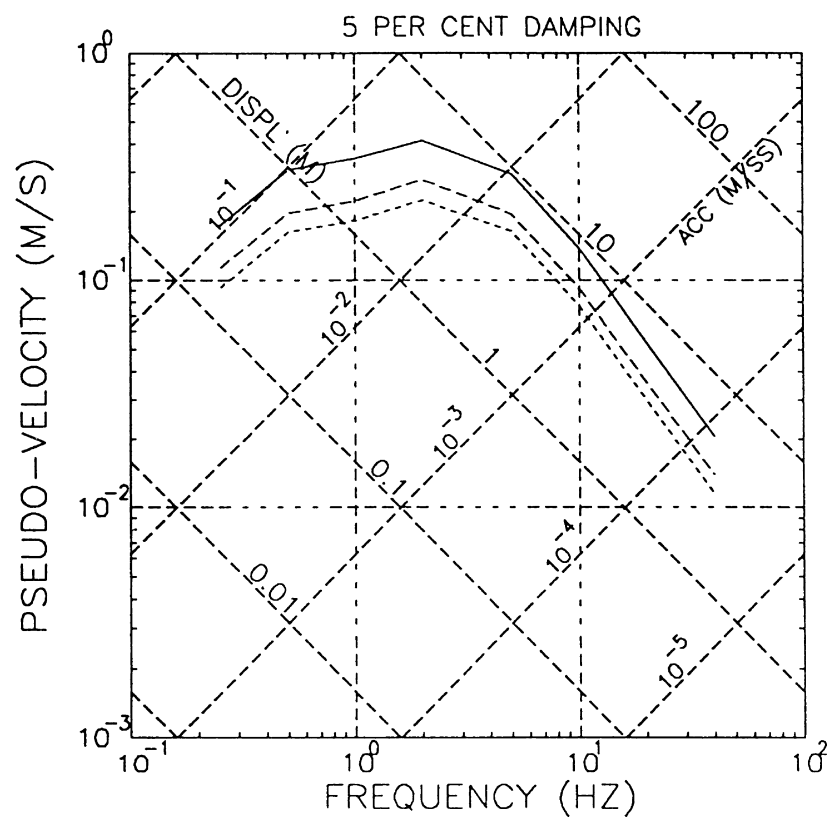

Fig. 10. Absolute uniform hazard spectrum for the city of San Jose for annual probabilities of $2 \times 10^{-2}, 10^{-2}$ and $2 \times 10^{-3}$ for the Central Valley region at $5 \%$ damping.
Table 10

Normalized PSV spectral ordinates $(\mathrm{m} / \mathrm{s})$, for bedrock condition, at annual exceedance probabilities $2 \times 10^{-2}, 10^{-2}$ and $2 \times 10^{-3}$ for the city of San Jose at $5 \%$ damping

\begin{tabular}{llll}
\hline Frequency $(\mathrm{Hz})$ & \multicolumn{3}{l}{ Annual exceedance probability } \\
\cline { 2 - 4 } & $2 \times 10^{-2}$ & $10^{-2}$ & $2 \times 10^{-3}$ \\
\hline 0.25 & 0.314250 & 0.317110 & 0.329437 \\
0.50 & 0.550167 & 0.550490 & 0.579910 \\
1.00 & 0.618336 & 0.623932 & 0.651439 \\
2.00 & 0.763044 & 0.776490 & 0.787175 \\
5.00 & 0.556808 & 0.547219 & 0.555733 \\
10.0 & 0.262378 & 0.257283 & 0.259857 \\
40.0 & 0.039039 & 0.039039 & 0.039039 \\
\hline
\end{tabular}

earthquakes in the country reactive this faulting generating seismic sequences and swarms. Historic and recent seismicity indicate that the faulting located in the borders of the Central Valley is active and can generate seismic events of 5-6 magnitude. Those seismic sources represent a great hazard for the cities of the Central Valley.

The soils in the San Jose Metropolitan area will be assessed in tasks parallel to this study, and preliminary results from these studies indicate that most of San Jose appears to be underlain by stiff silts and clays and therefore could amplify the ground motion. In the present study, however, the seismic hazard is estimated at bedrock level, with PGA values from 3.2 to $3.75 \mathrm{~m} / \mathrm{s}^{2}$ at exceedance probability $10^{-2} /$ year. Those values are $30 \%$ higher than

\section{San Jose site PSV for return periods of 50,100 and 500 years}

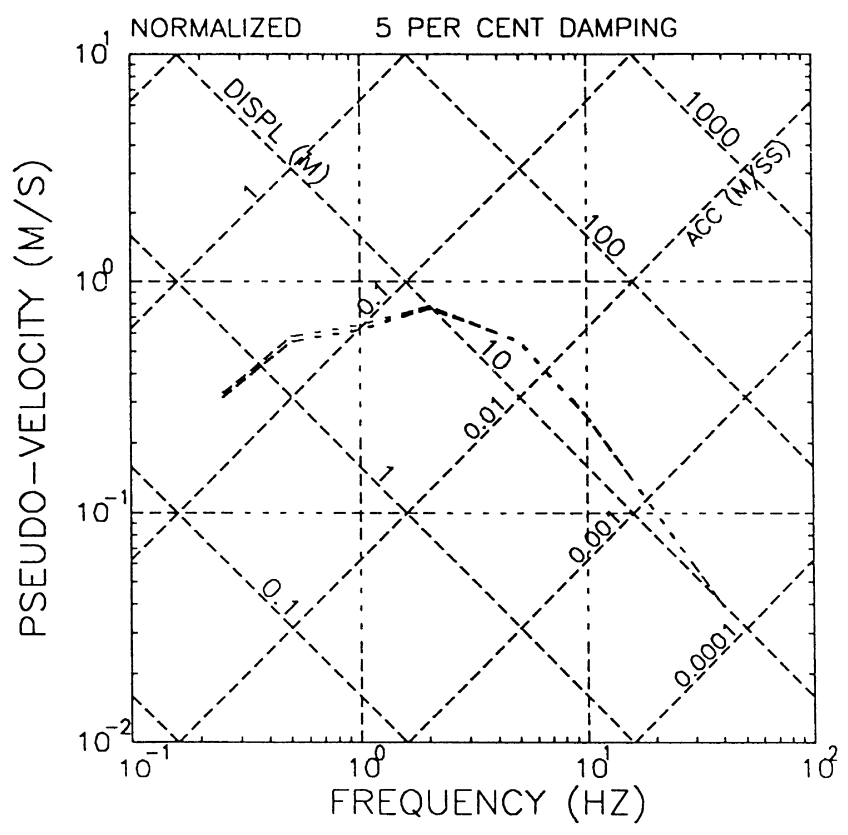

Fig. 11. Normalized uniform hazard spectrum for the city of San Jose for annual probabilities of $2 \times 10^{-2}, 10^{-2}$ and $2 \times 10^{-3}$ for the Central Valley region at $5 \%$ damping. 
previously obtained by Laporte et al. [14], due essentially to: (1) new attenuation relations; (2) more local seismicity data; and (3) the inclusion and use of active faults in the new seismotectonic model.

The highest values for the expected hazard (PGA) were obtained for the southern parts of San Jose and are in good agreement with the main seismic source contribution and the presence of shallow crustal active faults. Also, that region is topographically most varied and therefore more susceptible to landslides.

Equal hazard response spectra were computed for the central part of San Jose, for frequencies between 0.25 and $40 \mathrm{~Hz}$, and indicate a peak at around $2 \mathrm{~Hz}$. The computed, normalized spectra are evaluated as being representative for the metropolitan area of the Central Valley at bedrock level. The maximum velocity at $2 \mathrm{~Hz}$ for $2 \times 10^{-3}$ annual exceedance probability was found to be $0.28 \mathrm{~m} / \mathrm{s}$ for the $10^{-2}$ probability level.

A sensitivity analysis has demonstrated the relative importance of seismic parameter quality, as $N, b$, focal depth, $M_{\max }$ and $M_{\min }$.

In developing the source models in the study we have studied in detail the moment release from each of the seismic sources and totally for the region. The total moment release for the region is $0.88 \times 10^{24} \mathrm{dyn} / \mathrm{cm}^{2}$ and $0.418 \times 10^{24} \mathrm{dyn} / \mathrm{cm}^{2}$ is generated by active faults. However, a similar amount of energy release comes from faults not yet identified. From the total moment release a return period of about 40 years for a magnitude 6.0 earthquake has been obtained for the studied area. This agrees quite well with the historical records indicating a $35 \pm 6.0$ year return period for magnitude 6.0.

\section{Acknowledgements}

Thanks to CEPREDENAC and NORAD for the financial support to carry out this investigation. We also thank to the staff of the Red Sismologica Nacional (RSN: ICE-UCR) and the Seismic Engineering Laboratory of the University of Costa Rica for their help.

\section{References}

[1] González C. Temblores, terremotos, inundaciones y erupciones volcánicas en Costa Rica, 1608-1910. Tipografia de Avelino Alsina, San José, Costa Rica, 1910. p. 200.

[2] Tristán F, Biolley P, Cots C. The Sarchi Earthquake, Costa Rica. Bull Seismol Soc Am 1912;2:201-10.

[3] Montero W, Morales LD. Sismotectónica y niveles de actividad de microtemblores en el suroeste del Valle Central, Costa Rica. Rev Geofis: Inst Panam Geogr Hist 1984;21:21-41.

[4] Arias O, Denyer P. Estructura geológica de la región comprendida en las hojas topográficas Abra, Caraigres, Candelaria y RÍo Grande, Costa Rica. Rev Geol Am Central 1991;12:61-74.

[5] Fernández M, Montero W. Fallamiento y sismicidad entre Cartago y San José, 2000, in press.

[6] Protti M, Güendel F, McNally K. The geometry of the
Wadati-Benioff zone under southern Central America and its tectonics significance. Phys Earth Planet Int 1994;84:271-87.

[7] de Boer J, Drummond M, Bordelon M, Defant M, Bellon H, Maury R. Cenozoic magmatic phases of the Costa Rican island arc (Cordillera de Talamanca). In: Mann P, editor. Geologic and Tectonic Development of the Caribbean Plate Boundary in Southern Central America: Boulder, CO. Geological Society of America Special Paper 295, 1995.

[8] Bowin C. The Caribbean gravity field and plate tectonics. Geological Society of America Special Paper 169, 1976. p. 79.

[9] Matumoto T, Othake M, Latham G, Umaña J. Crustal structure of southern Central America. Bull Seismol Soc Am 1977;67(1):121-34.

[10] Havskov J, Lindholm C. The Seisan earthquake analysis software. Institute of Solid Earth Physics, University of Bergen, Bergen, Norway, 1992.

[11] Havskov J, Lindholm C. The Seisan earthquake analysis software. Institute of Solid Earth Physics, University of Bergen, Bergen, Norway, 1996.

[12] NORSAR. NPRISK user's guide, version 2.1. March 1999. NORSAR PO Box 51, N-2007 Norway, 1998. p. 35

[13] Camacho E, Lindholm C, Dahle A, Bungum H. Seismic hazard for Panama. Technical Report, NORSAR, 1994. p. 2-13.

[14] Laporte M, Lindholm C, Bungum H, Dahle A. Seismic hazard for Costa Rica. Technical Report, NORSAR, Norway, 1994. p. 2-14.

[15] Rojas W, Cowan H, Lindholm C, Dahle A, Bungum H. Regional seismic zonation for Central America: a preliminary model. Technical Report, NORSAR, Norway, 1993.

[16] Geomatrix Consultants. Sub-Estudio de la vulnerabilidad sÍsmica de la conducción: el Llano a Tres Ríos, Provincia de Cartago, Costa Rica. En: Project No. 2656, Geomatrix Consultans, Inc. San Francisco, CA, USA, 1994. p. 160.

[17] Rojas W, Fernández M, Mora M, Schmidt V. Estudio de amenaza sÍsmica y peligro volcánico para el proyecto industrial INTEL, en Belén de Heredia. En: Informe particular de la Fundación para la Investigación de la Universidad de Costa Rica para la empresa FPMG Ambiental, S.J. Costa Rica, 1997. p. 47.

[18] Borgia A, Burr J, Montero W, Morales LD, Alvarado G. Fault propagation folds associated with extensional slumping of the Central Volcanic Range: implications for large terrestrial and martian edificies. J Geophys Res 1990;95:14357-82.

[19] Boschini I. Incidencia de las fuentes sÍsmicas en la región Caribe de Costa Rica. Tesis de Licenciatura, Escuela de GeologÍa, Univ. de Costa Rica, 1989. p. 97.

[20] Arias O, Denyer P. Geologia de la hoja Rio Grande. Instituto Geografico Nacional, 1990.

[21] Montero W, Alvarado G. El temblor de Patillos del 30 de diciembre de 1952 (Ms 5,9) y el contexto neotectónico de la región del volcán Irazú, Costa Rica. Rev Geol Amer Central 1995;18:25-42.

[22] Montero W, Morales LD. Zonificación sísmica del Valle Central. En Memorias $4^{\circ}$ Seminario de Ingeniería Estructural, San José, Costa Rica, 1988.

[23] Fernández M, Mora M, Barquero R. Los procesos sísmicos del Volcán Irazú, Costa Rica. Rev Geol Am Central 1998;21:47-59.

[24] Alvarado G, Morales LD, Montero W, Rojas W, Climent A. Aspectos sismotectónicos y morfotectónicos en el extremo occidental de la Cordillera Volcánica Central de Costa Rica. Rev Geol Am Central 1998;9:75-98.

[25] Chinnery MA, North RG. The frequency of very large earthquakes. Science 1975;190:1197-8.

[26] Anderson JG, Luco JE. Consequences of slip rate constants on earthquake occurrence relations. Bull Seismol Soc Am 1983;73:471-96.

[27] Swan FH, Schwart PD, Cluff LS. Recurrence of moderate-to-large magnitude earthquakes produced by surface faulting on the Wacatch fault zone. Bull Seismol Soc Am 1980;70:1421-62.

[28] Papageorgiou AS, Aki K. A specific barrier model for the quantitative 
description of inhomogeneous faulting and the prediction of strong ground motion. Bull Seismol Soc Am 1983;73:693-722.

[29] Brune JN. Seismic moment, seismicity, and rate of slip along major fault zones. J Geophys Res 1968;73:777-84.

[30] Anderson J. Estimating the seismicity from geological structure for seismic-risk studies. Bull Seismol Soc Am 1979;69:135-58.

[31] Young R, Coppersmith K. Implications of fault slip rates and earthquake recurrence models to probabilistic seismic hazard estimates. Bull Seismol Soc Am 1985;75:939-64.

[32] Hanks T, Kanamori H. A moment magnitude scale. J Geophys Res 1979;84:2348-50.

[33] Okal E, Romanowicz B. On the variation of $b$-values with earthquake size. Phys Earth Planet Int 1994;87:55-76.

[34] Schmidt V, Dahle A, Bungum H. Costa Rican spectral strong motion attenuation. Technical Report, NORSAR, Norway, 1997.

[35] Climent A, Taylor W, Ciudad Real M, Strauch W, Villagran M, Dahle A, Bungum H. Spectral strong motion attenuation in Central America, Technical Report, NORSAR, 1994. p. 2-17.

[36] Arias O, Denyer P. Geologia de la hoja Caraigres. Instituto Geografico Nacional, 1990.

[37] Denyer P, Arias O. Geologia de la hoja Abra. Instituto Geografico Nacional, 1990.
[38] Denyer P, Arias O. Geologia de la hoja Candelaria. Instituto Geografico Nacional, 1990.

[39] Montero W, Madrigal R, Mora R, Seeley, M, Alt J, Cline M. Lineamemntes suggestive of recent fault activity. Unpublished, 1991.

[40] Montero W, Rojas W, Boschini I, Barquero R, Flores H. Neotectonica de la region de Puriscal. Origen de la sismicidad de mayo-diciembre de 1990. Memoria del $5^{\circ}$ Seminario Nacional de Geotecnia, San Jose, Costa Rica, 1991.

[41] Montero W. Sismicidad y neotectonica. In: Denyer P, Kussmaul S, editors. Atlas Geologico Gran Area Metropolitana. Editorial Tecnologica de Costa Rica, 1994. p. 147-60.

[42] Denyer P, Arias O, Soto G, Obando L, Salazar L. Mapa Geologico de la Gran Area Metropolitana. In: Denyer P, Kussmaul S, editors. Atlas Geologico Gran Area Metropolitana, Editorial Technologica de Costa Rica, 1994. p. 275.

[43] Soto G. Estructuras volcano-tectonicas del volcan Turrialba, Costa Rica, America Central. Memorias V Congreso Geologico Chileno, Tomo III, 1988. p. 163-75.

[44] Rojas W. Catálogo de sismicidad histórica y reciente en América Central: desarrolo y análisis. Tesis de Licenciatura, Universidad de Costa Rica, 1993. p. 91. 